\title{
PENGARUH MINAT BELAJAR DAN KECERDASAN EMOSIONAL TERHADAP PRESTASI BELAJAR SISWA KELAS XI IPS SMA NEGERI 1 PRAJEKAN KABUPATEN BONDOWOSO TAHUN AJARAN 2016/2017
}

\author{
Kabela Putri Rahmawati ${ }^{1}$, Sutrisno Djaja ${ }^{1}$, Bambang Suyadi ${ }^{1}$ \\ ${ }^{1}$ Program Studi Pendidikan, Fakultas Keguruan dan Ilmu Pendidikan, Universitas Jember \\ e-mail: sutrisnodjaja.fkip@unej.ac.id
}

\begin{abstract}
Abstrak
Penelitian ini dilakukan untuk mengetahui pengaruh yang signifikan dari minat belajar dan kecerdasan emosional terhadap prestasi belajar siswa kelas XI IPS SMA Negeri 1 Prajekan Kabupaten Bondowoso tahun ajaran 2016/2017 dan untuk mengetahui variabel yang dominan antara minat belajar dan kecerdasan emosional terhadap prestasi belajar siswa kelas XI IPS SMA Negeri 1 Prajekan Kabupaten Bondowoso tahun ajaran 2016/2017. Metode penentuan lokasi penelitian menggunakan metode purposive area yaitu di SMA Negeri 1 Prajekan Kabupaten Bondowoso.Penentuan jumlah responden dalam penelitian ini menggunakan metode populasiyaitu sebanyak 77responden. Metode pengumpulan data yang digunakan terdiri dari metode:angket, dokumen, dan wawancara.Analisis data yang digunakan adalahinferensial/statistik yaitu dengan menggunakan analisis garis regresi berganda, analisis varian garis regresi, uji F,efektivitas garis regresi, uji t, dan Standart Error Of Estimate. Hasil penelitian menunjukkan bahwa ada pengaruh yang signifikan variabel minat belajar dan kecerdasan emosional terhadap prestasi belajar siswa kelas XI IPS SMA Negeri 1 Prajekan Kabupaten Bondowoso tahun ajaran 2016/2017 yang dapat dilihat dari besarnya Fhitung $=184,364>$ Ftabel $=3$, 12 dengan tingkat signifikansi $\mathrm{F}=0,000<\mathrm{a}=0,05$. Besarnya persentase minat belajar dan kecerdasan emosional terhadap prestasi belajar siswa kelas sebesar 83,3\%,variabel yang dominan memengaruhi prestasi belajar siswa adalah minat belajar dengan besar persentase $47,57 \%$ dan kecerdasan emosional memberikan sumbangan sebesar $35,65 \%$, sedangkan sisanya yaitu $16,7 \%$ dipengaruhi variabel bebas lainnya yang tidak diteliti dalam penelitian ini.
\end{abstract}

Kata Kunci: Minat belajar, kecerdasan emoisonal, prestasi belajar

\section{PENDAHULUAN}

Pendidikan tidak terlepas dari kegiatan belajar dimana merupakan suatu proses yang dilakukan seseorang untuk mencapai suatu keinginannya. Pada saat proses belajar mengajar di sekolah, setiap siswa tentu berharap akan dapat mencapai prestasi yang baik dan memuaskan sesuai dengan usaha yang telah dilakukan. Prestasi belajar merupakan hasil belajar yang dicapai setelah melalui proses kegiatan belajar mengajar. Proses pembelajaran diharapkan dapat meningkatkan prestasi belajar siswa. Prestasi belajar siswa di sekolah menunjukkan keberhasilan siswa dalam proses belajar. Prestasi belajar dapat ditunjukkan melalui nilai yang diberikan oleh seorang guru dari jumlah bidang studi yang telah dipelajari oleh peserta didik.Setiap kegiatan pembelajaran siswa tentunya selalu mengharapkan menghasilkan pembelajaran yang maksimal dengan memperoleh prestasi yang baik.

Prestasi belajar dipengaruhi oleh beberapa faktor, dari sekian banyak faktor peneliti mengambil dari segi faktor yang muncul dari diri siswa dalam aspek psikologis yaitu minat belajar.Siswa yang mendapat prestasi tinggi maka dapat dikatakan siswa tersebut berhasil dalam belajarnya, agar siswa mendapatkan prestasi yang baik, maka siswa harus mempunyai minat belajar dalam mengikuti pembelajaran. Pentingnya minat belajar dalam proses pembelajaran sebagai perwujudan kewajiban seorang siswa untuk mencapai prestasi belajar yang maksimal. Oleh karena itu minat belajar siswa merupakan sebagian faktor yang memengaruhi prestasi belajar siswa yang patut diperhatikan. Minat belajar yang tumbuh dari dalam diri siswa itulah yang akan membuat siswa dapat mengikuti proses pembelajaran dengan senang, tertarik terhadap pelajaran, perhatian kepada guru, dan keterlibatan siswa 
dikelas, oleh karena itu siswa akan terpacu untuk selalu mendapatkan nilai yang baik.

Minat belajar siswa ditujukkan dengan siswa memiliki rasa senang selama mengikuti pembelajaran di kelas.Siswa memiliki antusiasme yang tinggi, siswa merasa tidak berat dalam mengerjakan tugas. Meskipun tugas yang diberikan guru dalam proses pembelajaran banyak, siswa bisa mengerjakan dengan tenang dan menyenangkan, siswa tidak akan putus asa dan tidak akan berkeluh kesah.

Dalam proses pembelajaran siswa yang tertarik terhadap materi pelajaran dapat ditunjukkan dengan siswa berusaha mencari informasi lain yang berkaitan dengan materi pelajaran yang diterima. Informasi tersebut bisa didapat siswa dari berbagai sumber misalnya dengan mencari dan membaca buku yang berkaitan dengan materi pelajaran atau dengan mencari informasi melalui jurnal dan internet.

Seorang siswa yang menaruh minat besar terhadap pelajaran akan memusatkan perhatian lebih banyak dari pada siswa lainnya. Siswa yang memiliki perhatian terhadap pelajaran akan berusaha konsentrasi dalam mendengarkan dan memahami materi yang disampaikan guru dengan mencatat poinpoin penting, siswa tidak akan mudah terganggu oleh lingkungan yang terjadi disekitar, misalnya terdapat suara gaduh, maka siswa tetap memperhatikan guru menjelaskan. Kemudian karena pemusatan perhatian yang intensif terhadap materi itulah yang memungkinkan siswa untuk belajar lebih giat lagi.Pada dasarnya siswa yang minat belajarnya tinggi, aktif dalam menemukan pengetahuan.

Dalam proses pembelajaran di kelas seorang siswa ikut terlibat dalam menerima materi pelajaran seperti bertanya kepada guru apabila terdapat materi yang kurang dipahami dan menjawab pertanyaan yang diberikan oleh guru. Pada saat diskusi terjadi maka siswa akan sepenuhnya mengikuti yang diperintahkan oleh guru dengan aktif berpendapat, dan bertukar pikiran dengan teman.

Fenomena yang terjadi sekarang ini di SMA Negeri 1 Prajekan dalam proses pembelajaran di kelas secara umum terlihat siswa mempunyai minat belajar yang tinggi. Hal tersebut ditunjukkan dengan keseriusan siswa dalam memperhatikan materi yang disampaikan guru dengan mendengarkan dengan penuh konsentrasi, dan mencatat poin-poin penting materi yang diterima, demikian siswa akan lebih mudah mengerjakan soal yang diberikan oleh guru. Pada saat diskusi siswa aktif berpendapat, saling bertukar pikiran, dan bekerja sama dengan kelompok belajarnya. Sehingga, pembelajaran di kelas menjadi kondusif karena adanya aktivitas siswa yang menunujukkan minat belajar yang baik.

Selain minat belajar yang harus ditumbuhkan dari dalam diri siswa, siswa juga harus dapat mengembangkan kecerdasan emosional secara optimal dalam proses pembelajaran. Kecerdasan emosional merupakan salah satu faktor terpenting dalam proses pembelajaran untuk dapat mencapai prestasi yang maksimal. Dengan kecerdasan emosional, diharapkan siswa dapat membangun sikap terpuji yang muncul dari hati dan akal.

Kecerdasan Emosional yang dimiliki siswa dapat ditujukkan dengan siswa dapat mengenali emosi dirinya misalnya siswa mampu mengenali, merasakan, bahkan menamai emosi dirinya yang dirasakan pada saat emosi itu muncul.Memahami penyebab perasaan yang timbul, yaitu setelah siswa mampu mengenal dan merasakan emosinya sendiri, siswa juga mampu untuk menemukan bahkan memahami penyebab perasaan emosinya yang timbul.

Dalam mengembangkan kecerdasan yang dimiliki siswa, siswa harus mampu mengelola emosi dirinya misalnya siswa yang bersikap toleran terhadap perasaannya, yaitu bagaimana siswa mentoleransi saat perasaannya sedang tidak baik.Mampu mengendalikan marah secara lebih baik, yaitu siswa mampu mengelola perasaan marahnya agar dapat dikendalikan secara lebih baik.

Dalam proses pembelajaran agar siswa dapat giat dalam mengikuti proses pembelajaran siswa mampu memotivasi dirinya ditujukkan dengan siswa dengan optimis, artinya siswa mampu untuk selalu merasa optimis dalam melakukan segala hal. Mampu memusatkan perhatian pada tugas yang dikerjakan, artinya siswa dapat bersikap tegas pada dirinya sendiri untuk konsentrasi dan fokus pada 
tugas yang dikerjakan serta tidak tergoda oleh hal lain yang dapat membuyarkan bahkan mengganggu konsentrasinya dalam mengerjakan tugas.

Dalam lingkungan sekolah dengan adanya interaksi dengan teman, dalam hal ini dapat ditunjukkan oleh siswa dengan mampu mengenali emosi orang lain atau teman dengan menerima sudut pandang orang lain, artinya siswa dapat bersikap terbuka untuk menerima dan memaklumi sudut pandang orang lain meskipun pandangan orang lain tersebut bertolak belakang. Memiliki sikap empati atau kepekaan terhadap perasaan orang lain dan mendengarkan orang lain yang mengajaknya berbicara.

Selain kemampuan mengenali emosi orang lain siswa dalam lingkungan sekolah juga harus membina hubungan yang baik kepada teman. Hal tersebut dapat ditujukkan oleh siswa dengan memiliki sikap bersahabat atau mudah bergaul dengan teman sebaya, mampu menyelesaikan konflik dengan teman secara positif dan tidak menimbulkan konflik yang baru, dan bersikap senang berbagi rasa dan bekerja sama dengan teman. Siswa dengan kemampuan ini cenderung mempunyai banyak teman dan pandai bergaul.

Fenomena yang terjadi sekarang ini di SMA Negeri 1 Prajekan dalam proses pembelajaran saat diskusi di kelas secara umum terlihat siswa mempunyai kecerdasan emosional yang tinggi, ketika teman kurang tepat dalam menjawab pertanyaan, maka ia mencoba memperbaiki jawaban tersebut dengan hati-hati sebelum bicara, menggunakan kata-kata yang sopan agar tidak menyinggung ataupun menyakiti perasaan teman. Selain itu dalam keseharian siswa di sekolah, di luar pembelajaran di kelas siswa terlihat akrab dengan teman, bersikap terbuka dan mudah bergaul dengan teman, dan saling tolong-menolong.Hal tersebut membuat situasi disekitar sekolah menjadi nyaman dan menyenangkan.

Berdasarkan uraian tersebut penulis tertarik untuk melakukan penelitian dengan judul "Pengaruh Minat Belajar dan Kecerdasan Emosional Terhadap Prestasi Belajar Siswa Kelas XI IPS SMA Negeri 1 Prajekan Kabupaten Bondowoso Tahun Ajaran 2016/2017”.

Ada penelitian yang sejenis yang dijadikan acuan bagi peneliti untuk melakuakan penelitian ini. Penelitian sejenis yang dilakukan oleh Ahmad Nafik Chusaini (2015) dengan judul "Pengaruh Kecerdasan Terhadap Hasil Belajar Siswa Kelas X IPS Mata Pelajaran Ekonomi SMA Negeri 1 Grati Kecamatan Nguling Kabuaten Pasuruan Tahun 2015", dan penelitian yang dilakukan oleh Raafiud Darajaad (2016) dengan judul "Pengaruh Minat Belajar dan Jam Belajar Terhadap Prestasi Belajar Siswa Pada Mata Pelajaran Ekonomi di Siswa Kelas XI IPS SMA Negeri 1 Kesamben Kabupaten Jombang".

Minat belajar merupakan faktor yang memengaruhi prestasi belajar siswa di sekolah. Minat belajar memiliki peran penting dalam proses pembelajaran di sekolah. Minat belajar siswa dapat dilihat dari kegiatan yang dilakukan siswa pada saat pembelajaran berlangsung.Menurut Hanen (dalam Susanto, 2014:57) minat belajar siswa erat hubungannya dengan kepribadian, motivasi, ekspresi, dan konsep diri atau identifikasi, faktor keturunan dan pengaruh eksternal atau lingkungan. Dalam praktiknya, minat atau dorongan dalam diri siswa terkait dengan apa atau bagaimana siswa dapat mengaktualisasikan dirinya melalui belajar. Secara sederhana minat belajar berarti kecenderungan dan kegairahan yang tinggi atau keinginan yang besar terhadap sesuatu (Syah, 2008:136). Selain minat belajar yang berpengaruh terhadap prestasi belajar siswa adalah kecerdasan emosional yang dimiliki siswa. Kecerdasan Emosional atau emotional intelligence merupakan kemampuan mengenali perasaan diri sendiri dan perasaan orang lain, kemampuan memotivasi diri sendiri, dan kemampuan mengelola emosi dengan baik pada diri sendiri dan dalam hubungan dengan orang lain (Golemen, 2005:512).

Prestasi merupakan salah satu hal yang utama dalam proses pembelajaran. Hal ini dikarenakan dalam suatu pembelajaran dikatakan berhasil jika prestasi belajar yang diperoleh siswa sudah sesuai dengan standar ketuntasan yang telah ditetapkan.Prestasi belajar siswa erat kaitannya dengan minat belajar dan tingkat kecerdasan emosional yang dimiliki oleh siswa. 
Bloom (dalam Susanto, 2014:59) menunjukkan bahwa prestasi dan minat belajarsaling berhubungan dan saling memengaruhi. Minat belajar merupakan salah satu faktor yang dapat memengaruhi prestasi belajar siswa. Minat belajar yang besar cenderung menghasilkan prestasi yang tinggi, sebaliknya minat belajar yang kurang akan menghasilkan prestasi yang rendah. Maka apabila seorang siswa mempunyai minat yang besar terhadap mata pelajaran ia akan memusatkan perhatian lebih banyak dari temannya, kemudian karena pemusatan perhatian yang intensif terhadap materi itulah yang memungkinkan siswa tersebut untuk belajar lebih giat, dan akhirnya mencapai prestasi yang tinggi.

Selain minat belajar yang berpengaruh terhadap prestasi belajar, menurut Gaedner (dalam Aunurrahman, 2014:88) menilai bahwa terbukti kecerdasan emosional memiliki peran yang signifikan dalam mengantarkan seseorang menuju puncak prestasi. Siswa yang mempunyai kecerdasan emosional yang bagus akan mampu mengendalikan emosinya sehingga otak berfungsi lebih baik, dapat memotivasi diri sendiri agar lebih cakap dalam belajar, sehingga akan lebih mudah berprestasi baik. Dengan demikian kecerdasan emosional berpengaruh terhadap prestasi belajar siswa.

Menurut Uno dan Kuadrat (2009:17) pentingnya kecerdasan emosional dikembangkan pada peserta didik.Peserta didik yang begitu cerdas di sekolah, begitu cemerlang prestasi akademiknya, namun tidak mampu mengelolah emosinya, seperti mudah marah, mudah putus asa, atau angkuh dan sombong sehingga prestasi tersebut tidak banyak bermanfaat untuk dirinya. Ternyata kecerdasan emosional perlu lebih dihargai dan dikembangkan pada peserta didik sejak usia dini karena hal inilah yang mendasari keterampilan peserta didik ditengah lingkungannya kelak akan membuat seluruh potensinya dapat berkembang secara optimal. Dengan demikian kecerdasan emosional berpengaruh terhadap prestasi belajar siswa.

Berdasarkan penjelasan tersebut, maka hipotesis dalam penelitian ini adalah ada pengaruh yang signifikan minat belajar dan kecerdasan emosional terhadap prestasi belajar siswa kelas XI IPS SMA Negeri 1 Prajekan Kabupaten Bondowoso Tahun Ajaran 2016/2017.

\section{METODE}

Penelitian ini merupakan penelitian kuantitatif korelasional, yaitu untuk mengetahui pengaruh yang signifikan dari minat belajar dan kecerdasan emosional terhadap prestasi belajar siswa kelas XI IPS SMA Negeri 1 Prajekan Kabupaten Bondowoso tahun ajaran 2016/2017 dan untuk mengetahui variabel yang dominan anatara minat belajar dan kecerdasan emosional terhadap prestasi belajar siswa kelas XI IPS SMA Negeri 1 Prajekan Kabupaten Bondowoso tahun ajaran 2016/2017. Metode penentuan lokasi penelitian menggunakan metode purposive area yaitu di SMA Negeri 1 Prajekan Kabupaten Bondowoso. Penentuan jumlah responden dalam penelitian ini menggunakan metode populasiyaitu sebanyak 77responden. Metode pengumpulan data yang digunakan terdiri dari metode: angket, dokumen, dan wawancara.Analisis data yang digunakan adalahinferensial/statistik yaitu dengan menggunakan analisis garis regresi berganda, analisis varian garis regresi, uji F,efektivitas garis regresi, uji t, dan Standart Error OfEstimate.Uji instrumen data dalam penelitian ini menggunakan uji validitas dan uji reliabilitas. Teknik pengolahan data dalam penelitian ini menggunakan editing, skoring, dan tabulasi. Analisis data yang digunakan adalahanalisis inferensial/statistik yaitu dengan menggunakan analisis garis analisis regresi bergaandadengan rumus sebagai berikut:

$$
\hat{\mathrm{Y}}=\mathrm{a}+\mathrm{b}_{1} \mathrm{X}_{1}+\mathrm{b}_{2} \mathrm{X}_{2}+e i
$$


Untuk analisis varian garis regresi yaitu untuk mengetahui kuat tidaknya atau tingkat keeratan variabelminat belajar dan kecerdasan emosional terhadap prestasi belajar siswa kelas XI IPS SMA Negeri 1 Prajekan Kabupaten Bondowoso tahun ajaran 2016/2017 yaitu dengan rumus sebagai berikut:

$$
R y=\sqrt{\frac{a_{1} \sum x_{1} y+a_{2} \sum x_{2} y}{\sum y^{2}}}
$$

Sedangkanuji F yaitu untuk mengetahui pengaruh yang signifikan variabel minat belajar dan kecerdasan emosional terhadap prestasi belajar siswa kelas XI IPS SMA Negeri 1 Prajekan Kabupaten Bondowoso tahun ajaran 2016/2017dengan rumus sebagai berikut:

$$
F=\frac{R 2 / K}{\left\{\left(1-R^{2}\right) /(N-K-1)\right\}}
$$

Selanjutnya, untuk uji t yaitu untuk mengetahui berapa pengaruh masing-masing variabel minat belajar dan kecerdasan emosional terhadap prestasi belajar siswa kelas XI IPS SMA Negeri 1 Prajekan Kabupaten Bondowoso tahun ajaran 2016/2017 dengan rumus sebagai berikut:

$$
\mathrm{t}=\sqrt[r]{\frac{N-K-1}{1-r^{2}}}
$$

\section{HASIL DAN PEMBAHASAN}

Hasil

Berdasarkan hasil analisis garis regresi bergandadiperoleh $\mathbf{R}_{\text {squaresebesar }} 0,833$. Koefisien determinasi $\mathbf{R}_{\text {square }}$ dalam penelitian ini digunakan untuk mengukur besarnya pengaruh variabel bebas (X) dan variabel terikat (Y). Jenis analisis ini digunakan untuk mengetahui pengaruh yang signifikan dari variabel bebas yaituvariabel minat belajar dan kecerdasan emosional terhadap prestasi belajar siswa kelas XI IPS SMA Negeri 1 Prajekan Kabupaten Bondowoso tahun ajaran 2016/2017. Berdasarkan analisis data yang dilakukandiperoleh hasil dalam tabel berikut ini:

Tabel Ringkasan Uji F, Multiple R, dan R Square

\begin{tabular}{ccccccc}
\hline Variabel & $\mathrm{F}_{\text {Hitung }}$ & $\mathrm{F}_{\text {Tabel }}$ & Sig. F & $a$ & $\mathrm{R}$ & $\mathrm{R}_{\text {Square }}$ \\
\hline Xterhadap Y & 184,364 & 3,12 & 0,000 & 0,05 & 0,913 & 0,833 \\
\hline
\end{tabular}

Sumber : Data diolah 2017

Tabel di atas menunjukkan bahwa $\mathrm{F}_{\text {hitung }}=184,364>\mathrm{F}_{\text {tabel }}=3,12$ dengan tingkat signifikansi $\mathrm{F}$ $=0,000<a=0,05$. Hal ini menunjukkan bahwa variabel minat belajar dan kecerdasan emosional berpengaruh signifikan terhadap prestasi belajar siswa kelas XI IPS SMA Negeri 1 Prajekan Kabupaten Bondowoso tahun ajaran 2016/2017.Untukkoefisien determinasi $R_{\text {Square }}$ sebesar 0,833 yang dengan proporsi sumbangansecara bersama-sama terhadap Y sebesar $83,3 \%$. sedangkan sisanya yaitu $16,7 \%$ dipengaruhi variabel bebas lainnya yang tidak diteliti dalam penelitian ini seperti kecerdasan intelektual, fasilitas belajar, teman sebaya, metode pembelajaran yang diajarkan guru, latar belakang orang tua, dan lain-lain.

Pembahasan

Berdasarkan penelitian yang dilakukan dapat diketahui bahwa adanya minat belajar dan kecerdasan emosional dapat mempengaruhi prestasi belajar siswa kelas XI IPS SMA Negeri 1 Prajekan Kabupaten Bondowoso Tahun Ajaran 2016/2017. Hal tersebut ditunjukkan dengan adanya hasil analisis 
data bahwa variabel minat belajar dan kecerdasan emosional berpengaruh signifikan terhadap prestasi belajar siswa kelas XI IPS SMA Negeri 1 Prajekan Kabupaten Bondowoso Tahun Ajaran 2016/2017 sebesar $83,3 \%$. Hal tersebut ditunjukkan dengan adanya hasil analisis data yang menunjukkan sumbangan variabel minat belajar sebesar 47,57\% dan kecerdasan emosional sebesar 35,65\%. Dimana variabel yang dominan mempengaruhi prestasi belajar adalah variabel minat belajar.Prestasi merupakan salah satu hal yang utama dalam proses pembelajaran. Hal ini dikarenakan dalam suatu pembelajaran dikatakan berhasil jika prestasi belajar yang diperoleh siswa sudah sesuai dengan standar ketuntasan yang telah ditetapkan.Prestasi belajar siswa erat kaitannya dengan minat belajar dan tingkat kecerdasan emosional yang dimiliki oleh siswa.

Minat belajar siswa erat hubungannya dengan kepribadian, motivasi, ekspresi, dan konsep diri atau identifikasi, faktor keturunan dan pengaruh eksternal atau lingkungan. Dalam praktiknya, minat atau dorongan dalam diri siswa terkait dengan apa atau bagaimana siswa dapat mengaktualisasikan dirinya melalui belajar. Oleh karena itulah minat belajar erat kaitannya dengan prestasi belajar kelas XI IPS SMA Negeri 1 Prajekan Kabupaten Bondowoso.Berikut merupakan penjelasan dari guru kelas XI IPS SMA Negeri 1 Prajekan Kabupaten Bondowoso yang menjadi informan dalam penelitian ini.

“......... Siswa yang memiliki minat belajar yang tinggi, maka prestasi belajar yang diperoleh juga akan tinggi mbak, sebaliknya jika siswa memiliki minat belajar yang rendah, maka prestasi belajar yang diperoleh juga akan rendah. Hal ini dikarenakan siswa yang mempunyal minat belajar tinggi akan selalu serius dalam mengikuti pembelajaran, mengerjakan tugas dengan tepat waktu, aktif dalam diskusi, serta belajar dengan giat ketika hendak mengikuti ulangan harian. Oleh karena itulah minat belajar erat kaitannya dengan prestasi belajar siswa mbak."(MI, 51 $\left.1^{\mathrm{Th}}\right)$.

Berdasarkan pendapat tersebut dapat diketahui bahwa minat belajar yang dimiliki oleh siswa erat kaitannya dengan prestasi belajar yang dihasilkan. Hal ini dikarenakan dengan adanya minat untuk belajar, maka siswa akan bersungguh-sungguh dalam mengikuti proses pembelajaran di sekolah, sehingga dapat memengaruhi prestasi belajar yang dihasilkan. Bloom (dalam Susanto, 2014:59) menunjukkan bahwa prestasi dan minat belajarsaling berhubungan dan saling memengaruhi. Minat belajar merupakan salah satu faktor yang dapat memengaruhi prestasi belajar siswa. Minat belajar yang besar cenderung menghasilkan prestasi yang tinggi, sebaliknya minat belajar yang kurang akan menghasilkan prestasi yang rendah. Maka apabila seorang siswa mempunyai minat yang besar terhadap mata pelajaran ia akan memusatkan perhatian lebih banyak dari temannya, kemudian karena pemusatan perhatian yang intensif terhadap materi itulah yang memungkinkan siswa tersebut untuk belajar lebih giat, dan akhirnya mencapai prestasi yang tinggi.

Selain itu, kecerdasan emosional yang dimiliki oleh siswa juga memengaruhi prestasi belajar siswa. Kecerdasan Emosional atau emotional intelligence merupakan kemampuan mengenali perasaan diri sendiri dan perasaan orang lain, kemampuan memotivasi diri sendiri, dan kemampuan mengelola emosi dengan baik pada diri sendiri dan dalam hubungan dengan orang lain (Golemen, 2005:512). Siswa yang memiliki kecerdasan emosional yang baik, tidak akanmengalami kesulitan dalam hal bergaul dengan teman, interaksi dengan guru, serta dalam menyelesaikan segala permasalahan yang dihadapi.

"Adanya kecerdasan emosional yang dimiliki oleh siswa juga dapat memengaruhi prestasi belajar siswa mbak. Siswa yang memiliki kecerdasan emosional yang baik maka siswa tersebut akan mudah bergaul, tidak mudah marah, mudah dalam menghadapi kesulitan yang dihadapi, serta dapat intropeksi diri ketika melakukan kesalahan. Dan tentu saja hal ini sangat 
mempengaruhi prestasi belajar siswa tersebut.Oleh karena itulah minat belajar dan kecerdasan emosional erat kaitannya dengan prestasi belajar siswa mbak" (MI, 51 ${ }^{\mathrm{Th}}$ ).

Berdasarkan pendapat tersebut dapat diketahui bahwa selain minat belajar, kecerdasan emosional juga berpengaruh terhadap prestasi belajar, menurut Gaedner (dalam Aunurrahman, 2014:88) menilai bahwa terbukti kecerdasan emosional memiliki peran yang signifikan dalam mengantarkan seseorang menuju puncak prestasi. Siswa yang mempunyai kecerdasan emosional yang bagus akan mampu mengendalikan emosinya sehingga otak berfungsi lebih baik, dapat memotivasi diri sendiri agar lebih cakap dalam belajar, sehingga akan lebih mudah berprestasi baik. Dengan demikian kecerdasan emosional berpengaruh terhadap prestasi belajar siswa.

Berdasarkan uraian di atas dapat disimpulkan bahwa minat belajar akan mendorong siswa belajar lebih baik dan kecerdasan emosional merupakan kemampuan untuk mengendalikan dan mempergunakan emosi ke arah yang positif dan produktif, dengan demikian minat belajar dan kecerdasan emosional berpengaruh terhadap prestasi belajar, semakin tinggi minat belajar dan kecerdasan emosional siswa maka semakin optimal pula prestasi belajar yang didapatkan siswa di sekolah.

Berdasarkan pemaparan diatas dapat disimpulkan bahwa variabel minat belajar dan kecerdasan emosional dapat mempengaruhi prestasi belajar siswa kelas XI IPS SMA Negeri 1 Prajekan Kabupaten Bondowoso Tahun Ajaran 2016/2017.Berdasarkan hasil penelitian dan pembahasan dalam penelitian ini membuktikan bahwa hipotesis pertama dalam penelitian ini diterima yaitu ada pengaruh yang signifikan minat belajar dan kecerdasan emosional terhadap prestasi belajar siswa kelas XI IPS SMA Negeri 1 Prajekan Kabupaten Bondowoso Tahun Ajaran 2016/2017.Hipotesis kedua juga diterima karena variabel minat belajar merupakan variabel yang dominan mempengaruhi prestasi belajar siswa kelas XI IPS SMA Negeri 1 Prajekan Kabupaten Bondowoso Tahun Ajaran 2016/2017.

\section{PENUTUP}

Berdasarkan analisis data dan pembahasan mengenai minat belajar dan kecerdasan emosional terhadap prestasi belajar siswa kelas XI IPS SMA Negeri 1 Prajekan Kabupaten Bondowoso Tahun Ajaran 2016/2017dapat disimpulkan bahwaada pengaruh yang signifikan minat belajar dan kecerdasan emosional terhadap prestasi belajar siswa kelas XI IPS SMA Negeri 1 Prajekan Kabupaten Bondowoso Tahun Ajaran 2016/2017 yaitu sebesar 83,3\%. Untuk pengaruh yang dominan terhadap prestasi belajar siswa kelas XI IPS SMA Negeri 1 Prajekan Kabupaten Bondowoso Tahun Ajaran 2016/2017 yaitu pada variabel minat belajar $\left(\mathrm{X}_{1}\right)$ sebesar 47,57\%.

Berdasarkan kesimpulan dari penelitian ini maka dapat diberikan saran pada beberapa pihak antara lain, bagi pihak guru, untuk lebih memperhatikan minat belajar dan kecerdasan emosional siswa, terutama pada saat proses pembelajaran berlangsung. Bagi siswa, untuk lebih meningkatkanminat belajar dan kecerdasan emosional yang dimilikinya dalam proses pembelajaran, serta untuk lebih memaksimalkan belajar agar dapat memperoleh prestasi belajar secara maksimal. Bagi peneliti lain, diharapkan bagi peneliti lain yang akan melakukan penelitian serupa dengan penelitian ini untuk mengambil variabel lain yang tidak turut diteliti dalam penelitian ini, supaya dapat menciptakan penelitian yang lebih baik dan nantinya sebagai tambahan referensi penelitian.

\section{DAFTAR PUSTAKA}

Aunurrahman. 2014. Belajar dan Pembelajaran. Bandung: Alfabeta.

Golemen, Daniel. 2001. Emotional Intelligence. Jakarta: Gramedia Pustaka Utama. 
Golemen, Daniel. 2005. Kecerdasan Emosi untuk Mencapai Puncak Prestasi. Jakarta:Gramedia Pustaka Utama.

Susanto, Ahmad. 2014. Teori Belajar Pembelajaran. Jakarta: Kencana Prenada Media Group.

Widyaningsih, Suri. 2013. Pengaruh Kecerdasan Emosional, dan Minat Belajar Terhadap Prestasi Belajar Akuntansi Keuangan Siswa Kelas XI IPS Program Keahlian Akuntansi SMK Negeri 1 Godean Tahun Ajaran 2012/2013.Jurnal Jurusan Pendidikan Akuntansi Fakultas Ekonomi Univesitas Negeri Yogyakarta.Vol 2 No 7 tahun 2013. 